Original Research Paper

\title{
Pelatihan Percakapan Bahasa Inggris Pariwisata Melalui Permainan Luar Ruang Bermakna (Meaningful Outdoor Plays) untuk Anak-anak di Sekitar Lokasi Pembangunan Sirkuit MotoGP Kawasan Ekonomi Khusus (KEK) Mandalika Lombok
}

\author{
Santi Farmasari ${ }^{1 *}$, Mahyuni ${ }^{1}$, Lalu Nurtaat ${ }^{1}$, Lalu Ali Wardana ${ }^{1}$

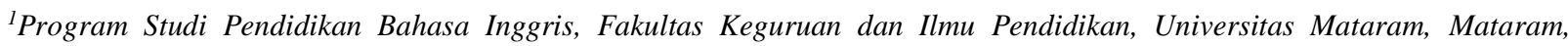 \\ Indonesia
}

DOI: https://doi.org/10.29303/jpmpi.v4i2.673

Sitasi: Farmasari, S., Mahyuni., Nurtaat, L., \& Wardana, L. A. (2021). Pelatihan Percakapan Bahasa Inggris Pariwisata Melalui Permainan Luar Ruang Bermakna (Meaningful Outdoor Plays) untuk Anak-anak di Sekitar Lokasi Pembangunan Sirkuit MotoGP Kawasan Ekonomi Khusus (KEK) Mandalika Lombok. Jurnal Pengabdian Magister Pendidikan IPA, 4(2)

\author{
Article history \\ Received: 03 Februari 2021 \\ Revised: 08 Maret 2021 \\ Accepted: 10 April 2021 \\ *Corresponding Author: Santi \\ Farmasari, Program Studi \\ Pendidikan Bahasa Inggris, \\ Fakultas Keguruan dan Ilmu \\ Pendidikan, Universitas \\ Mataram, Mataram, Indonesia; \\ Email: \\ santifarmasari@unram.ac.id
}

\begin{abstract}
Tujuan pengabdian pada masyarakat (PPM) ini adalah melatih dan membekali anak-anak usia SD kelas 4,5, dan 6 yang seringkali membantu keluarganya berjualan souvenir di sekitar KEK Mandalika Lombok Tengah dengan kemampuan komunikasi sederhana Bahasa Inggris pariwisata melalui permainan luar ruang bermakna (meaningful outdoor plays). Kegiatan PPM ini juga bertujuan untuk membantu pemerintah daerah mempersiapkan sumber daya manusia (SDM) di sekitar sirkuit MotoGP Mandalika Lombok Tengah. Kegiatan PPM ini dilaksanakan dengan tahapan (1) survey lokasi dan diskusi dengan kepala desa atau dusun, (2) desain rencana PPM, (3) penyusunan materi pelatihan, (4) pelatihan, dan (5) penyusunan laporan dan luaran PPM. Kegiatan PPM ini menghasilkan (1) pengetahuan khalayak strategis tentang percakapan sederhana pariwisata, (2) keterampilan berkomunikasi Bahasa Inggris sederhana untuk keperluan pariwisata khususnya penjualan souvenir, dan (3) manuskrip jurnal yang akan diterbitkan di jurnal PPM yang revelan. Kegiatan dan materi pelatihan ini disusun berdasarkan teori-teori dan metode-metode pembelajaran Bahasa Inggris anak-anak (English for Children) dan disesuaikan dengan karakter anak sebagai pembelajar usia dini (young learners).
\end{abstract}

Keywords: Outdoor plays bermakna; English for children; young learners; Kawasan Ekonomi Khusus Mandalika; sirkuit MotoGP Mandalika; komunikasi Bahasa Inggris.

\section{Pendahuluan}

Kawasan Ekonomi Khusus (KEK) Mandalika di Kabupaten Lombok Tengah Provinsi Nusa Tenggara Barat (NTB) merupakan kawasan perekonomian baru di provinsi Nusa Tenggara Barat (NTB) yang dicanangkan pemerintah melalui peraturan pemerintah nomor 52 tahun 2014. KEK Mandalika ini ditetapkan sebagai KEK khusus pariwisata yang diharapkan dapat mempercepat pengembangan sektor pariwisita NTB. Hal ini disebabkan oleh tingginya potensi kepariwisataan Kawasan Mandalika Lombok baik itu potensi pantai maupun bawah lautnya. Karena potensi inilah, pemerintah Republik Indonesia melalui 
Kementerian Kepariwisataan dan Ekonomi Kreatif menggelontorkan dana pengembangan KEK Mandalika dengan jumlah yang cukup fantastis yaitu di angka 40 Triliun dan diperkirakan akan membuka lapangan pekerjaan bagi lebih dari 500.000 (lima ratus ribu) orang (Dewan Nasional Kawasan Ekonomi Khusus Republik Indonesia, n.d.). Dalam pengembangannya, pariwisata KEK Mandalika diarahkan menjadi ecotourism atau pariwisata berbasis lingkungan dengan membangun obyek-obyek wisata dan daya tarik wisata yang tetap mengedepankan kelestarian lingkungan hidup, kelestarian adat dan budaya masyarakat setempat dan kelestarian nilai-nilai lokal (local values) di sekitarnya (Fennel, 2020).

Salah satu daya tarik wisata di KEK Mandalika yang diprediksi akan mencuri perhatian dunia adalah sirkuit internasional Moto Grand Prix atau MotoGP. Sirkuit ini nantinya akan menjadi salah satu sirkuit kejuaran internasional MotoGP di dunia dan diprediksi akan mulai digunakan mulai bulan Oktober tahun 2021 (Kencana, 2021) dan akan menjadi tuan rumah kejuaran internasional ini setiap tahunnya. Untuk mendukung percepatan pembangunan, beberapa infrastrukturpun sudah dan sedang dibangun diantaranya pembangunan infrastruktur sumber daya air, jalan, jembatan, permukiman dan perumahan. Pemerintah telah menganggarkan 1,7 triliun untuk pembangunan semua infrastruktur ini (Ramadani, 2020). Namun, dari semua konsep dan target pembangunan KEK Mandalika sebagai Kawasan ecotourism dan sirkuit MotoGP, penyiapan sumber daya manusia (SDM) di sekitar sirkuit MotoGP pada khususnya masih sangatlah terbatas. Padahal pemerintah daerah telah mengamanatkan bahwa proses pembangunan infrastruktur dan fasilitas pendukung event international MotoGP 2021 nantinya harus semaksimal mungkin memprioritaskan sumber daya lokal, baik itu dari tenaga kerja hingga bahan lokal milik masyarakat di sekitar kawasan tersebut (Pemerintah Provinsi Nusa Tenggara Barat, 2020). Selain janji akan manfaat ekonomi yang besar atas berdirinya sirkuit internasional ini, pemerintah pusat maupun daerah belum tampak memprogramkan kegiatan pengembangan sumber daya manusia di sekitar kawasan sirkuit. Satusatunya program pengembangan SDM yang disebutkan pemerintah daerah adalah Politeknik Pariwisata Lombok yang akan mendidik dan menghasilkan tenaga kerja pariwisata yang handal (Ridwan, 2016).

Politeknik Pariwisata Lombok ini memang akan menjadi harapan bagi ketersediaan tenaga kerja pariwisata yang handal, namun perlu juga dipahami bahwa masyarakat di sekitar sirkuit MotoGP inilah yang akan pertama kali merasakan dampak, baik positif maupun negatif, dari pembangunan sirkuit serta penyelenggaran event internasional nantinya. Masyarakat yang dimaksud ini adalah masyarakat segala usia, mulai dari anakanak hingga orang tua. Apabila kita menilik kawasan Mandalika secara keseluruhan, khususnya di kawasan yang ramai dikunjungi seperti Pantai Kuta atau Pantai Mandalika, banyak sekali kita jumpai anak-anak usia sekolah yang menjajakan souvenir atau barang-barang asongan di KEK Mandalika Lombok Tengah, seperti yang terlihat di photo-photo dibawah ini.

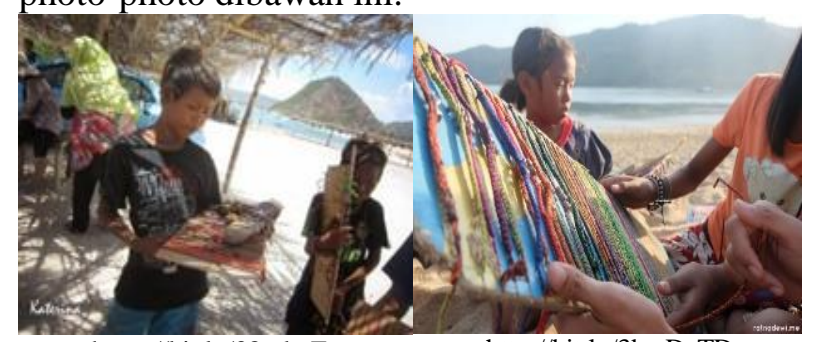

https://bit.ly/38mkoFp http://bit.ly/3bwDsTD

Gambar 1. Anak-anak pedagang souvenir di KEK Mandalika Lombok Tengah

Anggraini et al. (2020) dalam penelitiannya tentang anak-anak pedagang souvenir dan asongan di KEK Mandalika menemukan beberapa faktor yang menyebabkan anak-anak usia sekolah ini berjualan, yaitu faktor mengikuti teman sebaya, membantu ekonomi keluarga, pola asuh keluarga, longgarnya aturan sekolah, dan keinginan sendiri. Penomena ini memang kompleks, namun faktor ekonomi keluarga menjadi faktor utama anak-anak di sekitar KEK menjadi pedagang souvenir atau asongan. Oleh karena itu, sudah seyogyanya pembangunan SDM juga memperhatikan kebutuhan anak-anak yang harus bekerja ini. Berdasarkan beberapa kali kunjungan ke KEK, tim pengabdian ini menemukan fakta bahwa anak-anak pedagang souvenir dan asongan seringkali berinteraksi dengan tamu dari luar negeri. Berdasarkan kondisi ini, tim pengabdian ini berinisiatif untuk melaksanakan pengabdian pada masyarakat (PPM) dalam bentuk memberikan pelatihan Bahasa Inggris pariwisata kepada anak- 
anak di sekitar kawasan pembangunan sirkuit MotoGP agar mereka paling tidak bisa membuka dan melakukan komunikasi sederhana dengan para pengunjung internasional sirkuit MotoGP nantinya.

Yang perlu dipertegas dari kegiatan pelatihan ini adalah tujuan dari pelatihan Bahasa Inggris ini tidak mengarah pada dukungan memperkerjakan anak-anak usia sekolah dasar, namun lebih kepada mempersiapkan mereka mencapai cita-cita sesuai dengan konteks dan kebutuhan di lingkungan terdekat mereka. Selain itu, pelatihan ini juga memfasilitasi anak-anak untuk belajar, bermain, bergembira melalui outdoor plays yang sesuai dengan perkembangan fisik, psikologis, intelektual dan sosialnya (Prajnaparamita, 2018).

Sehubungan dengan kondisi pandemi Covid19 yang tidak memungkinkan pembelajaran di dalam ruangan, maka tim pengabdian mengaplikasikan permainan Bahasa Inggris luar ruang bermakna atau meaningful outdoor plays yang sesuai dengan karakter anak-anak sebagai pembelajar usia dini yang aktif dan suka bermain (Cameron, 2005; Ridwan, 2016) serta memperhatikan protokol kesehatan Covid-19.

\section{Metode}

Khalayak strategis pengabdian ini adalah anak-anak usia sekolah dasar (SD) kelas 4, 5 dan 6 yang tinggal di lingkungan terdekat dari sirkuit MotoGP Mandalika Lombok Tengah yang sedang dibangun. Kegiatan pengabdian ini dilaksanakan dengan metode pelatihan. berdasarkan permasalahan yang dijabarkan sebelumnya di bab latar belakang, solusi yang ditawarkan oleh tim pengabdian ini adalah memberikan pelatihan percakapan Bahasa Inggris pariwisata antara mereka (masyarakat sekitar lokasi sirkuit) dengan tamu luar negeri. Kegiatan pelatihan ini dilaksanakan melalui tahap-tahap berikut:

a. Survey lokasi dan komunikasi dengan kepala desa/dusun

Setelah memfinalisasi bentuk kegiatan, tim

PPM melaksanakan survey ke lokasi-lokasi sekitar lokasi pembangunan sirkuit MotoGP Mandalika Lombok Tengah dengan terlebih dahulu melakukan screening melalui google maps. Melalui google maps diperoleh beberapa desa dan dusun yang potensial menjadi lokasi pelatihan. Setelah teridentifikasinya beberapa desa dan dusun tersebut, tim PPM kemudian melakukan survey dan berkomunikasi dengan kepala desa atau kepala dusun setempat untuk mendapatkan informasi lebih lengkap tentang kebutuhan Bahasa Inggris untuk anak-anak di desa/dusun tersebut. Gambar 2 dibawah ini adalah tangkapan layar googlemaps lokasi survey PPM.

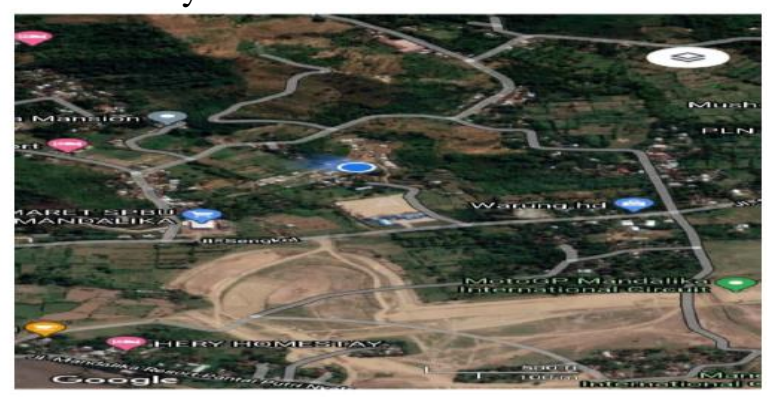

Gambar 2. Lokasi survey PPM

\section{b. Desain rencana pelaksanaan PPM}

Pada tahapan ini, tim PPM telah memfinalisasi lokasi pelatihan Bahasa Inggris. Berdasarkan survey dan komunikasi dengan kepala dusun, tim PPM mendapatkan informasi lengkap yang dibutuhkan untuk menyusun rencana pelaksanaan PPM, diantaranya jumlah anak sebagai khalayak strategis, rentang kelas, kebutuhan dan pengalaman belajar Bahasa Inggris, jenis permainan yang sering dilakukan anak-anak di dusun dan keperluan sekolah atau belajar di rumah yang mendesak untuk anak-anak tersebut. Selain itu, pada tahapan ini tim PPM menyusun indikatorindikator tercapainya target pelatihan.

\section{c. Penyusunan materi dan media/alat pelatihan \\ Output dari tahapan ini adalah} menghasilkan materi pelatihan beserta media atau alat yang akan digunakan untuk melatih Bahasa Inggris pariwisata untuk anak-anak. Materi dan media yang disiapkan diusahakan untuk memenuhi karakter pembelajaran English for Children (Cameron, 2005) dan karakter pembelajar anak usia dini yang aktif (Council of Europe, 2011; Vygotsky, 1962).

\section{d. Pelaksanaan pelatihan}

Pelatihan Bahasa Inggris untuk anak-anak di sekitar kawasan pembangunan sirkuit MotoGP Mandalika Lombok Tengah ini dilaksanakan melalui tahapan-tahapan berikut ini:

\section{- Pre-training}

Pre-training atau kegiatan awal pelatihan dilakukan dalam bentuk warmer game yang 
bertujuan untuk mempersiapkan anak-anak menerima materi pelatihan. Warmer game yang dilaksanakan adalah find someone who. Permainan ini bertujuan untuk melatih kemampuan anak-anak untuk mendengarkan (listening) instruksi, menghubungkan apa yang didengar dengan kondisi di sekitar (mengamati/observing), dan mentransfer apa yang didengar dan dilihat ke dalam bentuk aksi yang sesuai (acting). Kegiatan pre-training ini mengakomodasi perbedaan tipe pembelajar (learners' types), yaitu auditory melalui mendengarkan instruksi, visual melalui pengamatan sekitar, dan kinesthetic melalui aksi yang dilakukan Tabel 1. Tahapan pelatihan berdasarkan pendengaran dan pengamatan (Mckay, 2000; Prayatni, 2019).

\section{- Whilst-training}

Kegiatan inti pelatihan ini terfokus kepada pemberian pelatihan percakapan sederhana yang dibutuhkan anak-anak untuk memulai dan melakukan komunikasi interpersonal dengan tamu luar negeri. Whilst-training ini dilaksankan dengan tahapan sebagai berikut:

\begin{tabular}{|c|c|c|}
\hline Tahapan & Metode & Materi \& Kegiatan \\
\hline $\begin{array}{l}\text { Penyampaian } \\
\text { materi }\end{array}$ & $\begin{array}{l}\text { Observation } \\
\text { and Reflect }\end{array}$ & $\begin{array}{l}\text { Materi inti yang diberikan adalah (1) percakapan perkenalan, (2) menanyakan dan } \\
\text { memberikan alamat atau arah, dan (3) percakapan jual beli souvenir khas Lombok. Satu } \\
\text { contoh percakapan untuk tiga tujuan komunikasi diatas diberikan untuk kemudian } \\
\text { dicoba dipraktekkan bersama pelatih dan seorang teman }\end{array}$ \\
\hline \multirow[t]{3}{*}{$\begin{array}{l}\text { Pelatihan } \\
\text { aplikasi } \\
\text { materi }\end{array}$} & $\begin{array}{l}\text { Puzzle } \\
\text { games }\end{array}$ & $\begin{array}{l}\text { Kalimat-kalimat dalam percakapan ini dipotong-potong dan dituliskan ke dalam kartu- } \\
\text { kartu berwarna untuk membentuk puzzle games yang kemudian disusun oleh anak-anak } \\
\text { sesuai urutan percakapannya }\end{array}$ \\
\hline & Role Play & $\begin{array}{l}\text { Anak-anak bermain peran sebagai seorang tamu dan seorang warga mempraktekkan } \\
\text { percakapan dilengkapi dengan realia percakapan seperti barang-barang yang dijual } \\
\text { (souvenir, makanan, minuman) }\end{array}$ \\
\hline & Market play & $\begin{array}{l}\text { Lingkungan belajar diubah menjadi sebuah pasar mini, beberapa anak berperan sebagai } \\
\text { tamu dan beberapa orang lainnya sebagai pedagang dan warga lokal. Setiap anak } \\
\text { diberikan kartu peran dan contoh ungkapan-ungkapan yang diperlukan untuk sesuai } \\
\text { dengan perannya. Selanjutnya, anak-anak peserta pelatihan berinteraksi secara alami } \\
\text { sesuai dengan skenario dan peran masing-masing. }\end{array}$ \\
\hline
\end{tabular}

\section{- Post-training}

Kegiatan pasca pelatihan ini dilaksanakan untuk mengevaluasi penguasaan anak-anak peserta pelatihan terhadap materi pelatihan. Evaluasi dilaksanakan dengan permainan ask and response. Anak-anak dibagi menjadi 2 (dua) kelompok, kelompok laki-laki dan perempuan. Kelompok lakilaki mengucapkan satu pertanyaan yang diambil acak dari percakapan, dan kelompok perempuan menanggapi pertanyaan tersebut. Dalam kegiatan ini, tim PPM memperhatikan dan memperbaiki kalimat dan pengucapan (pronunciation) Bahasa
Inggris peserta pelatihan sesuai dengan pengucapan standar yang dipahami.

\section{e. Penyusunan laporan dan luaran PPM}

Tahap akhir dari PPM ini adalah penyusunan laporan dan luaran PPM. Penyusunan laporan dilaksakan dengan mengacu kepada pedoman penyusunan laporan dan pedoman penulisan manuskrip jurnal yang ditargetkan.

Secara singkat, tabel 1 dibawah ini merangkum tahapan-tahapan pelaksanaan PPM ini.

Table 2 Tahapan kegiatan dan metode pelaksanaan PPM

\begin{tabular}{clll}
\hline No & \multicolumn{1}{c}{ Tahapan Kegiatan } & \multicolumn{1}{c}{ Metode } \\
\hline 1 & Survey lokasi dan komunikasi dengan & Kunjungan ke lokasi-lokasi potensial dan diskusi dengan kepala \\
kepala desa/dusun & desa/dusun \\
2 & Desain rencana pelaksanaan PPM & Diskusi dan unjuk kerja \\
3 & Penyusunan materi dan media/alat pelatihan & Diskusi, unjuk kerja, koordinasi dan komunikasi \\
4 & Pelaksanaan pelatihan & Penyuluhan \& pelatihan \\
5 & Penyusunan laporan dan luaran PPM & Unjuk kerja \\
\hline
\end{tabular}




\section{Hasil dan Pembahasan}

Setelah melaksanakan survey dan komunikasi dengan kepala desa dan dusun di sekitar sirkuit MotoGP, tim PPM memutuskan untuk melaksanakan kegiatan di Desa Ebunut karena lokasinya yang paling dekat dengan sirkuit MotoGP. 24 (dua puluh empat) anak-anak usia kelas 4, 5 dan 6 SD dari desa ini mengikuti pelatihan PPM ini. Dusun ini harus direlokasi karena lokasinya yang tepat berada di dalam kawasan sirkuit. PPM ini dilaksanakan di lokasi pemukiman sementara (temporary shelters) Dusun Ebunut karena permukiman permanen mereka sedang dalam tahap pembangunan.

Photo-photo dibawah ini diambil pada saat pelatihan ketika anak-anak peserta PPM ini sedang melaksanakan role play. Karena kondisi lokasi yang cukup panas saat itu, maka pelatihan dilaksanakan di sebuah ruang terbuka dengan tetap memperhatikan protokol kesehatan Covid19 (mencuci tangan sebelum kegiatan, memakai masker, jumlah peserta tidak lebih dari 30 (tiga puluh) orang, dan berusaha untuk selalu menjaga jarak) dan konsep belajar outdoor plays.

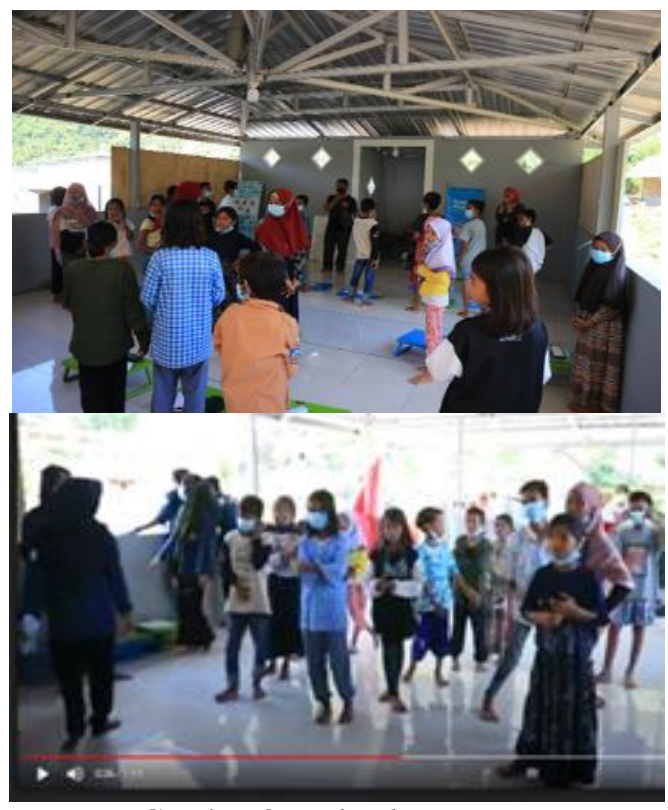

Gambar 3. Role play peserta

Seperti dalam photo-photo diatas, anakanak peserta pelatihan pada PPM ini tampak antusias untuk mengikuti pelatihan dari awal sampai akhir. Materi pelatihan yang disampaikan juga menurut mereka relevan dengan kebutuhan
Bahasa Inggris mereka ketika berinteraksi dengan tamu dari luar negeri di sekitar kawasan Mandalika. Mereka menyadari bahwa salah satu kesulitan yang mereka alami adalah kesulitan pengucapan beberapa kata dan keterbatasan kosakata yang mereka miliki. Sehingga, pelatihan ini dapat meningkatkan pengetahuan sekaligus keterampilan komunikasi mereka yang nantinya dapat mereka terapkan ketika berinteraksi dengan tamu-tamu luar negeri di kawasan sirkuit MotoGP Mandalika. Sehubungan dengan relevansi materi dan metode pelatihan dalam PPM ini, (Green, 2013) menyampaikan bahwa "All elements are given a degree of attention that reflects their relative importance in the curriculum or in the contexts where learners will need to use the language" (p.39). Artinya bahwa antusiasme belajar dapat dipengaruhi oleh tingkat kepentingan dan relevansi kurikulum atau materi dengan konteks dan kebutuhan nyata pembelajar.

Selain itu, tingkat relevansi materi yang disampaikan juga terlihat mempengaruhi keseriusan anak-anak peserta PPM ini. Selama pelatihan, diperolah beberapa indikator yang menunjukkan peningkatan pengetahuan dan keterampilan komunikasi Bahasa Inggris mereka, yaitu:

1) Peningkatan kosakata dan ungkapan-ungkapan yang lazim digunakan dalam percakapan sederhana dengan tamu luar negeri seperti kosakata, kalimat atau ungkapan-ungkapan yang lazim digunakan untuk sapaan (greetings) dan respon-responnya (responses), menanyakan dan memberikan arah (asking and giving directions), serta transaksi jual beli (shopping).

2) Perbaikan cara mengucapkan kata-kata, kalimat dan ungkapan-ungkapan yang diajarkan

3) Peningkatan kepercayaan diri anak-anak peserta PPM menggunakan Bahasa Inggris untuk komunikasi

4) Peningkatan keinginan atau motivasi untuk terus belajar Bahasa Inggris

Kegiatan pelatihan Bahasa Inggris untuk anak-anak ini berjalan lancar sesuai dengan rencana dan harapan walaupun dalam suasana pandemi Covid19. Dari serangkaian kegiatan pelatihan, terekam keinginan yang kuat dari anak-anak untuk tetap berlatih komunikasi dalam Bahasa Inggris untuk keperluan pariwisata menggunakan materi 
dan metode yang sudah diajarkan oleh tim PPM, serta tetap belajar Bahasa Inggris setelah kegiatan PPM ini berakhir. Selain itu, para peserta memberikan jawaban yang sangat antusias ketika tim menanyakan apakah mereka ingin dilibatkan kembali dalam kegiatan serupa dan mempraktekkannya langsung ke wisatawan yang ada di sekitar lingkungan mereka sehingga konteks dan kebutuhan Bahasa Inggris dapat disinergikan dengan baik (Gallego, 2016). Kelancaran dan keberhasilan PPM ini tidak lepas dari kerjasama dosen-dosen Pendidikan Bahasa Inggris FKIP Universitas Mataram yang terilbat sebagai tim PPM ini dengan pihak-pihak terkait, yaitu kepala Dusun Ebunut Kuta Lombok Tengah dan anak-anak di dusun ini yang bersedia dilibatkan sebagai khalayak strategis kegiatan PPM ini.

\section{Kesimpulan}

Berkat kerjasama yang baik antara tim PPM dan pihak-pihak terkait, kegiatan PPM ini berjalan dengan lancar dan sesuai rencana dan harapan serta mendapatkan respon positif dari kepala Dusun Ebunut dan anak-anak peserta pelatihan. Antusiasme dan partisipasi yang tinggi dari khalayak strategis disebabkan oleh kesesuaian materi dan metode pelatihan komunikasi Bahasa Inggris dengan kebutuhan dan karakter mereka sebagai pembelajar usia dini. Antusiasme ini nampak ketika anak-anak ditanya kesediaan mereka untuk dilibatkan kembali dalam kegiatan serupa, mempratekkannya langsung ke para tamu luar negeri dan keinginan untuk terus belajar Bahasa Inggris.

\section{Saran}

Untuk selanjutnya, perlu ada kunjungan pasca PPM ini untuk mengetahui apakah anak-anak khalayak strategis PPM ini memang tetap bersemangat untuk belajar Bahasa Inggris. Selain itu diperlukan pendampingan penggunaan materi yang telah dilatihkan secara nyata dengan tamutamu luar negeri yang ada di sekitar kawasan sirkuit MotoGP Mandalika. Selain itu, kunjungan berikutnya bisa menjajaki program-program lain yang dapat dilaksanakan oleh program studi Pendidikan Bahasa Inggris FKIP Universitas Mataram dalam membantu masyarakat terdampak pembangunan sirkuit MotoGP Mandalika Lombok Tengah.

\section{Ucapan Terima Kasih}

Terimakasih yang sebesar-besarnya disampaikan kepada semua pihak yang telah membantu terlaksananya program PPM ini, diantaranya (1) Kepala Dusun Ebunut Kuta Lombok Tengah, dan (2) anak-anak Dusun Ebunut sebagai khalayak strategis peserta pelatihan.

\section{Daftar Pustaka}

Anggraini, M., Nurjannah, S., \& Inderasari, O. P. 2020. Fenomena Pekerja Anak (Kasus Pedagang Asongan Anak di Kawasan Ekonomi Khusus Mandalika, Lombok Tengah). RESIPROKAL: Jurnal Riset Sosiologi Progresif Aktual, 2(1), 123-132. https://doi.org/10.29303/resiprokal.v2i1.22

Cameron, L. 2005. Teaching Languages to Young Learners. Cambridge University Press.

Council of Europe. 2011. Comes: Learning, Teaching, Assessment (CEFR) European Framework of Reference for Languag. Common European Framework. https://rm.coe.int/1680459f97

Dewan Nasional Kawasan Ekonomi Khusus Republik Indonesia. (n.d.). Tentang KEK Indonesia. Retrieved March 8, 2021, from https://kek.go.id/sekilas-tentang-indonesia

Fennel, D. A. 2020. Ecotourism. Routledge.

Gallego, J. G. 2016. International Perspectives on Teaching English to Young Learners. Issues in Teacher Education, 31, 192-195. https://search-proquestcom.alumniproxy.library.qut.edu.au/cv_19895 84/docview/1840798396/fulltextPDF/53A0B6 85EE4C49C5PQ/27? accountid $=31520$

Green, A. 2013. Exploring language assessment and testing: Language in action. Exploring Language Assessment and Testing: Language in Action, 14(2), 1-269. https://doi.org/10.4324/9781315889627

Kencana, M. R. B. 2021. Menparekraf Sandiaga Uno Yakin Bisa Gelar MotoGP Mandalika 
Oktober 2021. Liputan6, 1-4. https://www.liputan6.com/bisnis/read/445882 6/menparekraf-sandiaga-uno-yakin-bisa-gelarmotogp-mandalika-oktober-2021

Mckay, P. 2000. On ESL standards for school-age learners. Language Testing, 17(2), 185-214. https://doi.org/10.1177/026553220001700205

Pemerintah Provinsi Nusa Tenggara Barat. 2020. Proses Pembangunan Fasilitas MotoGP Diminta Maksimalkan Sumber Daya Lokal. https://www.ntbprov.go.id/post/programunggulan/proses-pembangunan-fasilitasmotogp-diminta-maksimalkan-sumber-dayalokal

Prajnaparamita, K. 2018. Perlindungan Tenaga Kerja Anak. Administrative Law and Governance Journal, 1(2), 215-230. https://doi.org/10.14710/alj.v1i2.215-230

Prayatni, I. 2019. Teaching english for young learners. Jurnal Ilmiah Profesi Pendidikan, 4(2), 106-110.

Ramadani, P. I. 2020. Jadi Tuan Rumah Motogp 2021, Intip Penampakan Proyek Infrastruktur di Mandalika. 1-4. https://www.liputan6.com/bisnis/read/442894 4/jadi-tuan-rumah-motogp-2021-intippenampakan-proyek-infrastruktur-dimandalika

Ridwan, M. F. 2016. Gubernur NTB: Pembangunan SDM di KEK Mandalika Harus Prioritas. Republika, $1-4$. https://www.republika.co.id/berita/o15rj9359/ gubernur-ntb-pembangunan-sdm-di-kekmandalika-harus-prioritas

Vygotsky, L. 1962. Thought and language. Cambridge University Press. 